Article

\title{
Improvement of the Content and Uptake of Micronutrients in Spring Rye Grain DM Through Nitrogen and Sulfur Supplementation
}

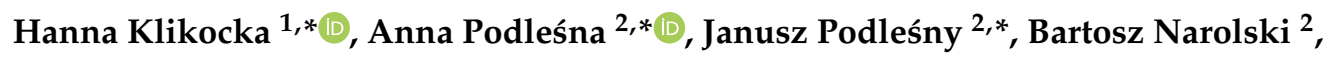 \\ Silvia Haneklaus ${ }^{3}$, Elke Bloem ${ }^{3}$ and Ewald Schnug ${ }^{3}$ \\ 1 Department of Economics and Agribusiness, Faculty of Agrobioengineering, University of Life Sciences in \\ Lublin, Akademicka 15, 20-950 Lublin, Poland \\ 2 Institute of Soil Science and Plant Cultivation, State Research Institute, Czartoryskich 8, \\ 24-100 Puławy, Poland; bartosz.narolski@gmail.com \\ 3 JKI-Julius Kühn Institut, Federal Research Centre for Cultivated Plant, Bundesallee 50, 38116 \\ Braunschweig, Germany; silvia.haneklaus@julius-kuehn.de (S.H.); elke.bloem@julius-kuehn.de (E.B.); \\ ewald.schnug@julius-kuehn.de (E.S.) \\ * Correspondence: hanna.klikocka@up.lublin (H.K.); ap@iung.pulawy.pl (A.P.); jp@iung.pulawy.pl (J.P.)
}

Received: 20 October 2019; Accepted: 23 December 2019; Published: 25 December 2019

\begin{abstract}
The aim of this field experiment was to analyze the influence of different nitrogen and sulfur doses on yield as well as the content and uptake of iron $(\mathrm{Fe})$, manganese $(\mathrm{Mn})$, copper $(\mathrm{Cu})$ and zinc (Zn) by spring rye grain. The study was conducted in south-eastern Poland (2009-2011) on Cambisols (WRB 2015), in conditions of low sulfur content in soil. The experiment included four doses of $\mathrm{N}$ fertilization $\left(0,30,60\right.$ and $\left.90 \mathrm{~kg} \mathrm{ha}^{-1}\right)$ and two doses of $\mathrm{S}$ supplementation $(0$ and $40 \mathrm{~kg} \mathrm{ha}^{-1}$ ). The analysis showed that fertilization with $\mathrm{N}$ and $\mathrm{S}$ had a positive effect on the studied features of spring rye. The highest grain yields were found after use of $90 \mathrm{~kg} \mathrm{~N} \mathrm{ha}^{-1}$. The grain of rye fertilized with these doses of $\mathrm{N}$ was characterized by the highest concentration and uptake of tested microelements. The supplementation of sulfur in a dose of $40 \mathrm{~kg} \mathrm{~S} \mathrm{ha}^{-1}$ improved the nitrogen effect, because the rye grain yield and the content and uptake of micronutrients (except $\mathrm{Mn}$ ) by rye grain dry mass increased. The highest yield of spring rye grain and accumulation of $\mathrm{Mn}$ and $\mathrm{Zn}$ and intake of $\mathrm{Mn}, \mathrm{Zn}$ and $\mathrm{Cu}$ by grain dry mass (DM) were obtained in the vegetation season of 2011, which was characterized by an optimal rainfall distribution. The highest accumulation of $\mathrm{Fe}$ and $\mathrm{Cu}$ and intake of Fe were obtained in the vegetation season of 2009. Significant correlations were found also between grain yield and the content and uptake of all studied micronutrients. The supplementation of NPK fertilization with sulfur can be a good means of agronomic biofortification for spring rye in order to increase the content and uptake of $\mathrm{Fe}, \mathrm{Mn}, \mathrm{Zn}$ and $\mathrm{Cu}$.
\end{abstract}

Keywords: agronomic biofortification; micronutrients; nitrogen; sulfur; spring rye

\section{Introduction}

Mineral fertilization in modern agriculture is the basic factor in plant cultivation and the main way to increase the amount of minerals in the plant. Mineral fertilization can be considered as a method of supplementation or biofortification to reduce malnutrition. In this case, it is a process of increasing the desired minerals or vitamins in the main crop of plants. As a result, food quality can also be modified [1,2].

Earlier conducted research also indicates the effectiveness of the use of sulfur on the increase of macro- and microelements in potato tubers and cereal grains [2-4]. The use of sulfur is important because of its deficiency in many regions of the world $[5,6]$. The low $\mathrm{SO}_{2}$ emissions into the atmosphere 
and sulfur deficiency in soils in several parts in Poland and many countries of the world have led to the necessity of $\mathrm{S}$ fertilizer use to enhance the production and quality of crops [5-7]. In Poland, in 1980, the emission (deposition) of $\mathrm{SO}_{2}$ per 1 ha was about $130 \mathrm{~kg} \mathrm{~S}$, while at present it is on average $18.7 \mathrm{~kg}$ $\mathrm{SO}_{2} \mathrm{ha}^{-1}$ [5]. In Poland, in 2015, a low content (I) of sulfate sulfur was found in 198 monitoring points (91.7\% of all profiles), which was a similar result to that observed in 2010. These studies showed a perceptible drop in the mean sulfur content in soils during the last years from 1.38 to $1.00 \mathrm{mg} \mathrm{S}-\mathrm{SO}_{4}$ $100 \mathrm{~g}^{-1}$, respectively, for 1995 and 2015 [8].

Crop fertilization with sulfur and nitrogen is a very current problem. The lack of scientific studies on the fertilization of crops with sulfur is the result of the fact that, in Poland, the positive balance of this component in agro-ecosystems was maintained for many years, resulting from high emissions of $\mathrm{SO}_{2}$ into the atmosphere in the country. Ecological activities aimed at reducing $\mathrm{SO}_{2}$ emissions into the atmosphere have meant that, starting from the second half of the 1980s in Western Europe, a negative sulfur balance in soil was observed [5]. However, the available studies mainly showed that plants require sulfur fertilization, such as Brassicaceae (oilseed rape), Liliaceae (garlic, onion), sugar beet, potato, Fabaceae plants and wheat [9]. There is no research on the sulfur fertilization of spring rye. Rye is an important bread and feed plant in Europe; in particular, the most rye is cultivated in the Russian Federation, Poland and Germany. The total production of these three countries accounts for $57.66 \%$ of global rye production. The highest consumption of rye is in Poland and Belarus, at on average $29.9 \mathrm{~kg}$ per capita per year. Cereals and cereal products provide about $30 \%$ of the energy and protein and $54 \%$ of the carbohydrates in the daily diet of contemporary human beings. Apart from energy nutrients, they are a rich source of many bioactive substances and nutrients [10].

As we know, sulfur metabolism in the plant is closely related to nitrogen metabolism and is not only physiological and biochemical but also an environmental problem [11]. Sulfur deficiency reduces the efficiency of the operation and use of fertilizer nitrogen by field crops. This fact allowed us to formulate the following working hypothesis of the undertaken research: the use of sulfur in the cultivation of spring rye improves the efficiency of nitrogen fertilization, leading to better growth and yielding of plants and a better supply of grain, which is valuable for human and animal body microelements.

To verify the hypothesis, a field experiment was carried out in 2009-2011 to determine the yield, content and uptake of microelements by spring rye-specifically the Bojko cultivar. The first experimental factor was nitrogen fertilization, and the second was the application of sulfur fertilization. In effect, the optimal combination of $\mathrm{N}+\mathrm{S}$ dose for grain yield and content as well as for $\mathrm{Fe}, \mathrm{Mn}$, $\mathrm{Zn}$ and $\mathrm{Cu}$ uptake was selected.

\section{Materials and Methods}

\subsection{Field Experiment}

The presented research was conducted as a three-year field experiment located in south-eastern Poland $\left(50^{\circ} 42^{\prime} \mathrm{N}, 23^{\circ} 15^{\prime} \mathrm{E}\right)$. A two-factor study was conducted in a randomized split-plot design (with four replications) (see Figure S1 in the Supplementary Material for a comprehensive dataset analysis). The soil in the experiment was marked as Cambisols (WRB 2015), consisting of light silty sand [12], containing $68 \%$ sand, $31 \%$ silt and $1 \%$ clay. The soil was characterized by a high content of $P$, an average content of $\mathrm{K}$ and $\mathrm{Mg}$, as well as low total and available sulfur. The content of $\mathrm{Mn}, \mathrm{Zn}$ and $\mathrm{Cu}$ in the soil was determined as high and Fe as average. The soil reaction was slightly acidic (Table 1). 
Table 1. Chemical characteristics of the soil layer of $0-20 \mathrm{~cm}$ (before sowing).

\begin{tabular}{|c|c|c|c|c|c|}
\hline Specification & Method of Analysis & Unit of Measure & Year 2009 & Year 2010 & Year 2011 \\
\hline $\begin{array}{l}\mathrm{pH}(0.01 \mathrm{~mol} / \mathrm{L} \\
\left.\mathrm{CaCl}_{2}\right)\end{array}$ & $\begin{array}{l}\text { Potentiometry with using a } \\
\text { Methrohm- } 605 \mathrm{pH} \text { meter }\end{array}$ & & 5.6 & 5.7 & 5.8 \\
\hline C-total & $\begin{array}{l}\text { Combustion by LECO EC- } 12^{\circledR} \\
\text { analyzer }\end{array}$ & \multirow{2}{*}{$\mathrm{g} \mathrm{kg}^{-1}$} & 9.2 & 8.9 & 7.7 \\
\hline $\mathrm{N}$-total & Kjeldahl's method & & 0.9 & 0.9 & 0.7 \\
\hline $\mathrm{N} \min$ & $\begin{array}{l}\mathrm{N}-\mathrm{NO}_{3}+\mathrm{N}-\mathrm{NH}_{4} \times 1.38 \text { (soil } \\
\text { bulk density, } \mathrm{mg} \mathrm{m}^{-3} \text { ) } \\
(\mathrm{PN}-\mathrm{R}-04038: 1997)\end{array}$ & $\mathrm{kg} \mathrm{ha}^{-1}$ & 72.8 & 68.4 & 64.9 \\
\hline $\mathrm{P}$-available & $\begin{array}{l}\text { Double lactate extraction and } \\
\text { measurement by colorimetric } \\
\text { assay-Egner-Riehm DL } \\
\text { method (PN-R-04023:1996) }\end{array}$ & \multirow{9}{*}{$\mathrm{mg} \mathrm{kg}^{-1}$} & 54.5 & 53.5 & 48.3 \\
\hline K-available & $\begin{array}{l}\text { Extraction: see above } \\
\text { phosphorus. Measurement by } \\
\text { photometric method. } \\
\text { (PN-R-04022:1996) }\end{array}$ & & 88.6 & 85.2 & 79.6 \\
\hline $\mathrm{Mg}$-available & $\begin{array}{l}\text { Extraction by } 0.0125 \mathrm{~m} \mathrm{~L}^{-1} \\
\mathrm{CaCl}_{2} \text { and measurement by } \\
\text { AAS. PN-R-04020-1994 }\end{array}$ & & 34.8 & 33.7 & 35.1 \\
\hline S-total & $\begin{array}{l}\text { By ICP-AES mineralization with } \\
\mathrm{HNO}_{3}+\mathrm{Mg}\left(\mathrm{NO}_{3}\right)_{2}\end{array}$ & & 102.8 & 86.3 & 72.0 \\
\hline $\mathrm{S}_{-} \mathrm{SO}_{4}$-available & $\begin{array}{l}\text { Extraction with } 0.025 \mathrm{~m} \mathrm{~L}^{-1} \mathrm{KCl} \\
\text { and measurement by } \\
\text { ion-chromatography }\end{array}$ & & 14.2 & 12.6 & 10.3 \\
\hline $\mathrm{Fe}$-total & \multirow{4}{*}{$\begin{array}{l}\text { Extraction by } 3 \mathrm{HCl}+\mathrm{HNO}_{3} \\
\text { (PN-ISO 11466:2002) and } \\
\text { measurement by AAS. } \\
\text { PN-ISO-11047:2001. }\end{array}$} & & 853.0 & 966.1 & 930.5 \\
\hline Mn-total & & & 398.2 & 466.3 & 462.7 \\
\hline $\mathrm{Zn}$-total & & & 24.9 & 33.8 & 31.6 \\
\hline $\mathrm{Cu}$-total & & & 9.8 & 10.7 & 11.9 \\
\hline
\end{tabular}

The subject of the presented experiment was spring rye (Secale cereale L.), variety Bojko. Rye was fertilized with nitrogen and sulfur according to the scheme presented in Table 2. Nitrogen was used as ammonium nitrate $\left(\mathrm{NH}_{4} \mathrm{NO}_{3}-34 \% \mathrm{~N}\right.$, including ammonia $\mathrm{N}\left(\mathrm{N}-\mathrm{NH}_{4}\right)-17.0 \%$ and nitrate $\mathrm{N}$ $\left(\mathrm{N}-\mathrm{NO}_{3}-17.0 \%\right)$. The sulfur was added in two forms: (I) prior to rye sowing, as kieserite $\left(\mathrm{MgSO}_{4} \times\right.$ $\mathrm{H}_{2} \mathrm{O}: 5.1 \% \mathrm{Mg}$ and $20.0 \% \mathrm{~S}$ ), and (II) as a foliar application on the rye plants during the vegetation phase (BBCH 55-59) in the form of Epsom salts (magnesium sulfate heptahydrate- $\mathrm{MgSO}_{4} \times 7 \mathrm{H}_{2} \mathrm{O}$; $10.2 \% \mathrm{Mg}$ and $32 \% \mathrm{SO}_{3}$ ). Prior the sowing of rye, fertilization with phosphorus (in an amount of $39.6 \mathrm{~kg} \mathrm{P} \mathrm{ha}^{-1}$ as granulated triple superphosphate) and with potassium (in an amount of $83 \mathrm{~kg} \mathrm{~K} \mathrm{ha}^{-1}$ in a potassium salt form) was performed.

Table 2. The doses of nitrogen (N) and sulfur (S) application.

\begin{tabular}{|c|c|c|c|c|c|c|c|c|}
\hline \multirow{3}{*}{ Fertilizer } & \multirow{2}{*}{\multicolumn{2}{|c|}{ Total Dose (kg ha-1) }} & \multicolumn{6}{|c|}{ Time and Dose of Fertilization } \\
\hline & & & \multicolumn{2}{|c|}{ Spring, Before Sowing } & \multicolumn{2}{|c|}{$\mathrm{BBCH}^{+} 30-31$} & \multicolumn{2}{|c|}{ ВВСН 55-59 } \\
\hline & $\mathrm{kg} \mathrm{ha}^{-1}$ & kg plot ${ }^{-1}$ & $\mathrm{~kg} \mathrm{ha}^{-1}$ & kg plot ${ }^{-1}$ & $\mathrm{~kg} \mathrm{ha}^{-1}$ & kg plot ${ }^{-1}$ & $\mathrm{~kg} \mathrm{ha}^{-1}$ & kg plot ${ }^{-1}$ \\
\hline \multirow{4}{*}{$\begin{array}{l}\text { Nitrogen } \\
(\mathrm{N})\end{array}$} & 0 & 0 & - & - & - & - & - & - \\
\hline & 30 & 0.09 & 30 & 0.09 & - & - & - & - \\
\hline & 60 & 0.18 & 30 & 0.09 & 30 & 0.09 & - & - \\
\hline & 90 & 0.27 & 30 & 0.09 & 30 & 0.09 & 30 & 0.09 \\
\hline Sulfur (S) & 40 & 0.12 & 30 & 0.09 & - & - & 10 & 0.03 \\
\hline
\end{tabular}


The agrotechnical procedures for spring rye cultivation were in accordance with current integrated production (IP) recommendations. Depending on the climatic-soil conditions, sowing was carried out between the third decade of March and the first decade of April, whereas the harvest was performed on the third decade of July or the first decade of August (at BBCH 89-92). The sowing rate of seeds was $140 \mathrm{~kg} \mathrm{ha}^{-1}$, which gave a density of 350 plants per $\mathrm{m}^{2}$. Before sowing, the kernels were treated with Vitavax 200 FS (active substance: carboxin + tiram) in an amount of $300 \mathrm{~mL} 100 \mathrm{~kg}^{-1}$. At the tillering stage (BBCH 28), herbicides (Granstar 75 WG-tribenuron-methyl (20 g ha $\left.{ }^{-1}\right)$ ) plus Puma Super 069 EW-fenoxaprop-P-ethyl (1 L ha $\left.{ }^{-1}\right)$ were used to control dicotyledonous and monocotyledonous weeds. To prevent lodging, a Stabilan 750 SL (chlormequat chloride) regulator was used at an amount of $1.8 \mathrm{~L} \mathrm{ha}^{-1}$ during the stem shooting phase (BBCH 30-31). However, plant protection products were not used to combat diseases and pests, due to the lack of proposed recommendations by the Institute of Plant Protection, Poznań, Poland.

The main meteorological parameters are presented in Table 3. The rainfall and air temperature during the vegetation time (III-VIII) were determined by the Selyaninov's hydrothermal coefficient. According to these calculations, the 2009 growing period was rather dry, and on the borderline to the optimal value (1.3). The other two vegetation periods (2010 and 2011) were defined as optimal to rather wet (1.6).

Table 3. Selyaninov's hydrothermal coefficient of the sum of rainfall $(\mathrm{mm})$ and mean air temperature $\left({ }^{\circ} \mathrm{C}\right)$ of the vegetation periods (2009-2011) and the long-term averages (1981-2005).

\begin{tabular}{|c|c|c|c|c|c|c|c|c|c|}
\hline \multirow{2}{*}{ Years } & \multicolumn{6}{|c|}{ Months (k) } & \multicolumn{3}{|c|}{ Sum-Mean (III-VIII) } \\
\hline & III & IV & V & VI & VII & VIII & $\mathbf{K}^{+}$ & $\mathrm{p}$ & $t$ \\
\hline 2009 & 5.31 & 0.52 & 2.43 & 2.13 & 0.41 & 0.82 & 1.32 & 349.13 & 2652 \\
\hline 2010 & 1.82 & 1.11 & 2.01 & 1.12 & 2.11 & 1.33 & 1.61 & 443.41 & 2715 \\
\hline 2011 & 1.23 & 1.13 & 0.71 & 1.02 & 2.72 & 2.30 & 1.62 & 414.62 & 2581 \\
\hline 1981-2005 & 5.12 & 1.82 & 1.51 & 1.62 & 1.71 & 1.01 & 1.62 & 367.72 & 2353 \\
\hline
\end{tabular}

\subsection{Analysis and Calculations}

After the harvest of spring rye, the grain yield (at $11 \%$ moisture content) was calculated. The 24 average grain samples from each year of research (2009-2011) were chemically analyzed in the laboratory of the Agricultural Chemical Station in Lublin for the content of iron (Fe), manganese $(\mathrm{Mn})$, zinc $(\mathrm{Zn})$ and copper $(\mathrm{Cu})$. The chemical properties of grain were determined according to the Accreditation Certificate of Testing Laboratory No AB 1186 (KQ/PB-16) and with the PN-EN-14084:2004 standard. The determination of micronutrient content in the grain samples was performed by the use of the AAS (atomic absorption spectrometry) method with a Varian SpectrAA 280 FS spectrophotometer (Varian, Inc., Palo Alto, CA, USA) and Varian lamp, at a current of $5 \mathrm{~mA}$ under flame acetylene/air (stochiometric ratio). The analysis of iron (Fe), manganese (Mn), zinc ( $\mathrm{Zn})$ and copper $(\mathrm{Cu})$ content was performed at the following wavelengths: $248.3 \mathrm{~nm}$, slit $0.2 \mathrm{~nm} ; 279.5 \mathrm{~nm}$, slit $0.2 \mathrm{~nm} ; 213.9 \mathrm{~nm}$, slit $1.0 \mathrm{~nm}$; and $324.8 \mathrm{~nm}$, slit $0.5 \mathrm{~nm}$, respectively.

For the calculation and the statistical analysis of the results, we used analysis of variance (ANOVA). The significance of differences was calculated with use of the Tukey test ( $p=0.05$ and 0.01 ). The mean results were determined with post-hoc analysis. The relationships between the tested features were determined by the analysis of Pearson linear correlation. The statistical analyses were calculated with the Statistica 10 (StatSoft Inc.: Tulsa, OK, USA, 2010; StatSoft Polska, Sp. zo.o. Kraków, Poland 2010) and Excel 7.0 (2007 Microsoft Office System) programs.

\section{Results and Discussion}

The analysis of the ANOVA of the presented results proved a significant positive influence of $\mathrm{N}$ fertilization on the rye grain yield and on the concentration and uptake of microelements $(\mathrm{Fe}, \mathrm{Mn}$, 
$\mathrm{Zn}$ and $\mathrm{Cu}$ ) by its whole-grain dry mass (DM) (see Tables 4 and 5, and Tables S1 and S2 in the Supplementary Material for the comprehensive dataset analysis). The performed statistical analysis did not show any interaction between the used doses of nitrogen and sulfur. The experimental year was significant for all studied features. The interaction between $\mathrm{N}$ fertilization and the year of study was significant only for the yield of grain and Cu uptake by the whole-grain DM of spring rye. The interaction between $\mathrm{S}$ fertilization and the year of study was not significant.

Table 4. Results of ANOVA statistical calculations for the studied features of spring rye grain yield $\left(\mathrm{t} \mathrm{ha}^{-1}\right)$, as well as content (mg kg${ }^{-1}$ ) and uptake $\left(\mathrm{g} \mathrm{ha}^{-1}\right)$ of Fe and Mn by whole-grain dry mass (DM).

\begin{tabular}{|c|c|c|c|c|c|c|c|c|c|c|c|}
\hline \multirow{2}{*}{ Variable $(n=24)$} & \multirow{2}{*}{ DF } & \multicolumn{2}{|c|}{ Grain Yield } & \multicolumn{2}{|c|}{ Fe Content } & \multicolumn{2}{|c|}{ Fe Uptake } & \multicolumn{2}{|c|}{ Mn Content } & \multicolumn{2}{|c|}{ Mn Uptake } \\
\hline & & F-Value & $p$-Value & F-Value & $p$-Value & F-Value & $p$-Value & F-Value & $p$-Value & F-Value & $p$-Value \\
\hline$S$ & 1 & 24.34 & 0.0026 & 32.36 & 0.0013 & 38.47 & 0.0008 & 60.07 & 0.0002 & 9.05 & 0.0238 \\
\hline $\mathrm{N}$ & 3 & 979.11 & 0.0001 & 25.27 & 0.0008 & 156.26 & 0.0001 & 33.72 & 0.0004 & 426.57 & 0.0001 \\
\hline $\mathrm{Y}$ & 2 & 58.00 & 0.0001 & 23.97 & 0.0014 & 12.71 & 0.0070 & 65.37 & 0.0001 & 96.59 & 0.0001 \\
\hline $\mathrm{S} \times \mathrm{N}$ & 3 & 0.98 & 0.4635 & 0.75 & 0.5601 & 0.78 & 0.5485 & 2.52 & 0.1549 & 4.00 & 0.0702 \\
\hline$S \times Y$ & 2 & 0.01 & 0.9943 & 2.32 & 0.1790 & 2.13 & 0.2002 & 7.70 & 0.0220 & 4.25 & 0.0710 \\
\hline $\mathrm{N} \times \mathrm{Y}$ & 6 & 19.91 & 0.0010 & 0.63 & 0.7064 & 2.02 & 0.2074 & 2.89 & 0.1108 & 1.40 & 0.3471 \\
\hline
\end{tabular}

Explanations: S-sulfur dose; $\mathrm{N}$-nitrogen dose; $\mathrm{Y}$-year; $\mathrm{S} \times \mathrm{N}$-sulfur dose $\times$ nitrogen dose; $\mathrm{S} \times \mathrm{Y}$-sulfur dose $\times$ year; $\mathrm{N} \times \mathrm{Y}$-nitrogen dose $\times$ year; $\mathrm{DF}$ - degrees of variable freedom; F-value — estimation F of variance analysis; $p$-value of F-variance ratio.

Table 5. Results of ANOVA statistical calculations for the studied features of spring rye content $\left(\mathrm{mg} \mathrm{kg}^{-1}\right)$ and uptake $\left(\mathrm{g} \mathrm{ha}^{-1}\right)$ of $\mathrm{Zn}$ and $\mathrm{Cu}$ by whole-grain DM.

\begin{tabular}{cccccccccc}
\hline \multirow{2}{*}{ Variable $(\boldsymbol{n}=\mathbf{2 4 )}$} & DF & \multicolumn{2}{c}{ Zn Content } & \multicolumn{2}{c}{ Zn Uptake } & \multicolumn{2}{c}{ Cu Content } & \multicolumn{2}{c}{ Cu Uptake } \\
\cline { 3 - 9 } & & F-Value & $\boldsymbol{p}$-Value & F-Value & $\boldsymbol{p}$-Value & F-Value & $\boldsymbol{p}$-Value & F-Value & $\boldsymbol{p}$-Value \\
\hline $\mathrm{S}$ & 1 & 37.07 & 0.0009 & 41.44 & 0.0007 & 25.24 & 0.0024 & 32.70 & 0.0012 \\
$\mathrm{~N}$ & 3 & 19.74 & 0.0016 & 329.96 & 0.0001 & 40.25 & 0.0002 & 355.06 & 0.0001 \\
$\mathrm{Y}$ & 2 & 140.10 & 0.0001 & 943.1 & 0.0001 & 121.34 & 0.0001 & 85.25 & 0.0001 \\
$\mathrm{~S} \times \mathrm{N}$ & 3 & 0.64 & 0.6143 & 0.48 & 0.7088 & 0.45 & 0.7267 & 0.41 & 0.7499 \\
$\mathrm{~S} \times \mathrm{Y}$ & 2 & 4.78 & 0.0573 & 2.31 & 0.1800 & 0.46 & 0.6534 & 0.40 & 0.6897 \\
$\mathrm{~N} \times \mathrm{Y}$ & 6 & 0.88 & 0.5619 & 1.64 & 0.2810 & 2.50 & 0.1447 & 5.12 & 0.0337 \\
\hline
\end{tabular}

Explanations: S-sulfur dose; $\mathrm{N}$-nitrogen dose; $\mathrm{Y}$-year; $\mathrm{S} \times \mathrm{N}$-sulfur dose $\times$ nitrogen dose; $\mathrm{S} \times \mathrm{Y}$-sulfur dose $\times$ year; $\mathrm{N} \times \mathrm{Y}$-nitrogen dose $\times$ year; $\mathrm{DF}$ — degrees of variable freedom; F-value-estimation $\mathrm{F}$ of variance analysis; $p$-value of F-variance ratio.

\subsection{Nitrogen}

In our presented research, each applied level of nitrogen fertilization (30, 60 and $\left.90 \mathrm{~kg} \mathrm{ha}^{-1}\right)$ had a significant positive effect on spring rye grain yield. However, the highest grain yields were found after the use of $90 \mathrm{~kg} \mathrm{~N} \mathrm{ha}^{-1}\left(3.68 \mathrm{tha}^{-1}\right)$. This yield increased by about $28.5 \%$ compared to the control. The concentration of microelements in the grain of spring rye increased together with the increase of the nitrogen dose and was the highest after the use of $90 \mathrm{~kg} \mathrm{~N} \mathrm{ha}^{-1}(\mathrm{Fe}-33.65, \mathrm{Mn}-39.48$, $\mathrm{Zn}-37.50$ and $\left.\mathrm{Cu}-4.65 \mathrm{mg} \mathrm{kg}^{-1} \mathrm{DM}\right)$. The accumulation of micronutrients in the whole-grain DM also statistically significantly increased at the same time as the increasing $\mathrm{N}$ fertilization rate and was the highest after the use of $90 \mathrm{~kg} \mathrm{~N} \mathrm{ha}^{-1}\left(\mathrm{Fe}-124.02, \mathrm{Mn}-145.40, \mathrm{Zn}-138.17\right.$ and $\mathrm{Cu}-17.14 \mathrm{mg} \mathrm{ha}^{-1}$ ) (see Table 6, Figure S2A and Tables S1 and S2 in the Supplementary Material for the comprehensive dataset analysis). 
Table 6. The influence of nitrogen $(\mathrm{N})$ and sulfur $(\mathrm{S})$ application on the grain yield $\left(\mathrm{t} \mathrm{ha}^{-1}\right)$ and content $\left(\mathrm{mg} \mathrm{kg}^{-1}\right)$ and uptake $\left(\mathrm{g} \mathrm{ha}^{-1}\right)$ of micronutrients by spring rye whole-grain DM.

\begin{tabular}{|c|c|c|c|c|c|c|c|c|c|c|}
\hline \multicolumn{2}{|c|}{ Fertilization } & \multirow{2}{*}{ Grain Yield $\left(t \mathrm{ha}^{-1}\right)$} & \multicolumn{2}{|c|}{$\mathrm{Fe}$} & \multicolumn{2}{|c|}{ Mn } & \multicolumn{2}{|c|}{$\mathrm{Zn}$} & \multicolumn{2}{|c|}{$\mathrm{Cu}$} \\
\hline$S$ & $\mathbf{N}$ & & Content & Uptake & Content & Uptake & Content & Uptake & Content & Uptake \\
\hline \multirow{4}{*}{$0 \mathrm{~S}(\mathrm{~N} \times \mathrm{S})$} & 0 & $2.59 \mathrm{a}$ & $26.53 \mathrm{a}$ & $68.38 \mathrm{a}$ & $37.00 \mathrm{a}$ & 95.97 a & 34.37 a & 89.33 a & $4.08 \mathrm{a}$ & $10.55 a$ \\
\hline & 30 & $2.80 \mathrm{a}$ & $28.70 \mathrm{a}$ & 80.17 a & $38.27 \mathrm{a}$ & 107.10 a & $34.77 \mathrm{a}$ & $97.26 \mathrm{a}$ & $4.28 \mathrm{a}$ & $11.99 \mathrm{a}$ \\
\hline & 60 & $3.55 \mathrm{a}$ & $29.87 \mathrm{a}$ & $106.18 \mathrm{a}$ & $40.20 \mathrm{a}$ & $142.93 \mathrm{a}$ & 35.97 a & $127.82 \mathrm{a}$ & $4.34 \mathrm{a}$ & $15.45 \mathrm{a}$ \\
\hline & 90 & $3.66 \mathrm{a}$ & $31.70 \mathrm{a}$ & $115.98 \mathrm{a}$ & $40.87 \mathrm{a}$ & 149.48 a & $36.47 \mathrm{a}$ & $133.40 \mathrm{a}$ & $4.59 \mathrm{a}$ & $16.80 \mathrm{a}$ \\
\hline \multirow{4}{*}{$50 \mathrm{~S}(\mathrm{~N} \times \mathrm{S})$} & 0 & $2.68 \mathrm{a}$ & $29.03 \mathrm{a}$ & $77.61 \mathrm{a}$ & $35.30 \mathrm{a}$ & $94.70 \mathrm{a}$ & $35.50 \mathrm{a}$ & $95.41 \mathrm{a}$ & $4.22 \mathrm{a}$ & $11.30 \mathrm{a}$ \\
\hline & 30 & $2.92 \mathrm{a}$ & $30.57 \mathrm{a}$ & $89.18 \mathrm{a}$ & 37.30 a & $109.04 \mathrm{a}$ & $36.43 \mathrm{a}$ & $106.35 \mathrm{a}$ & $4.48 \mathrm{a}$ & $13.09 \mathrm{a}$ \\
\hline & 60 & $3.61 \mathrm{a}$ & $32.93 \mathrm{a}$ & $118.98 \mathrm{a}$ & $37.73 \mathrm{a}$ & $136.30 \mathrm{a}$ & $37.30 \mathrm{a}$ & $134.64 \mathrm{a}$ & $4.55 \mathrm{a}$ & $16.44 \mathrm{a}$ \\
\hline & 90 & $3.71 \mathrm{a}$ & $35.60 \mathrm{a}$ & $132.05 \mathrm{a}$ & $38.10 \mathrm{a}$ & $141.32 \mathrm{a}$ & 38.53 a & $142.93 \mathrm{a}$ & $4.71 \mathrm{a}$ & $17.48 \mathrm{a}$ \\
\hline \multirow{2}{*}{ Mean (S) } & OS & $3.15 \mathrm{~B}$ & $29.20 \mathrm{~B}$ & $92.68 \mathrm{~B}$ & $39.08 \mathrm{~A}$ & $123.87 \mathrm{~A}$ & 35.92 B & 111.95 B & $4.33 \mathrm{~B}$ & $13.70 \mathrm{~B}$ \\
\hline & $40 \mathrm{~S}$ & $3.23 \mathrm{~A}$ & $32.03 \mathrm{~A}$ & $104.50 \mathrm{~A}$ & 37.11 B & $120.34 \mathrm{~B}$ & $36.94 \mathrm{~A}$ & $119.83 \mathrm{~A}$ & $4.49 \mathrm{~A}$ & $14.58 \mathrm{~A}$ \\
\hline \multirow{4}{*}{ Mean $(\mathrm{N})$} & $\begin{array}{c}0 \\
\mathrm{~N}\end{array}$ & $2.63 \mathrm{D}$ & $27.78 \mathrm{D}$ & $72.99 \mathrm{D}$ & $36.15 \mathrm{C}$ & $95.34 \mathrm{D}$ & $34.93 \mathrm{D}$ & $92.37 \mathrm{D}$ & $4.15 \mathrm{D}$ & $10.92 \mathrm{D}$ \\
\hline & $\begin{array}{l}30 \\
\mathrm{~N}\end{array}$ & $2.86 \mathrm{C}$ & $29.63 \mathrm{C}$ & $84.68 \mathrm{C}$ & $37.78 \mathrm{~B}$ & $108.07 \mathrm{C}$ & $35.60 \mathrm{C}$ & $101.80 \mathrm{C}$ & $4.38 \mathrm{C}$ & $12.54 \mathrm{C}$ \\
\hline & $\begin{array}{l}60 \\
\mathrm{~N}\end{array}$ & $3.58 \mathrm{~B}$ & $31.40 \mathrm{~B}$ & $112.58 \mathrm{~B}$ & $38.97 \mathrm{~A}$ & $139.62 \mathrm{~B}$ & $36.63 \mathrm{~B}$ & $131.23 \mathrm{~B}$ & $4.45 \mathrm{~B}$ & $15.95 \mathrm{~B}$ \\
\hline & $\begin{array}{l}90 \\
\mathrm{~N}\end{array}$ & $3.68 \mathrm{~A}$ & $33.65 \mathrm{~A}$ & $124.02 \mathrm{~A}$ & $39.48 \mathrm{~A}$ & $145.40 \mathrm{~A}$ & $37.50 \mathrm{~A}$ & 138.17 A & $4.65 \mathrm{~A}$ & $17.14 \mathrm{~A}$ \\
\hline \multirow{3}{*}{ Mean $(\mathrm{Y})$} & 2009 & $3.11 \mathrm{~B}$ & $32.99 \mathrm{~A}$ & $103.60 \mathrm{~A}$ & $36.46 \mathrm{C}$ & $113.80 \mathrm{C}$ & $33.18 \mathrm{~B}$ & $103.61 \mathrm{C}$ & $4.62 \mathrm{~A}$ & $14.47 \mathrm{~B}$ \\
\hline & 2010 & $3.14 \mathrm{~B}$ & $28.94 \mathrm{~B}$ & $92.13 \mathrm{C}$ & 37.83 B & 119.33 B & $37.98 \mathrm{~A}$ & 119.84 B & $4.05 \mathrm{C}$ & $12.78 \mathrm{C}$ \\
\hline & 2011 & $3.31 \mathrm{~A}$ & $29.92 \mathrm{~B}$ & 99.97 B & $40.00 \mathrm{~A}$ & 133.19 A & $37.35 \mathrm{~A}$ & $124.22 \mathrm{~A}$ & $4.55 \mathrm{~B}$ & $15.17 \mathrm{~A}$ \\
\hline
\end{tabular}

$\mathrm{ABC}$, abc-different letters in the same column means significant differences between results at $p \leq 0.05$.

Numerous scientific reports show that the amount of macro- and micronutrient accumulation depends on many factors. These include, for example, the plant type, species and variety [13], climate and soil conditions [14] as well as other agronomic and production factors. According to Ragaee et al. [15] rye grain (obtained from the Experimental Farm at UAE University) is ample in Fe and Mn. In turn, Kan [16] indicates that rye (cultivated on sand-loam soil) has the highest content of $\mathrm{Zn}$ among major cereal species. The grain of rye cultivated on a lessive soil of a medium silty loam and fertilized with NPK $\left(203 \mathrm{~kg} \mathrm{ha}^{-1}\right)$ in north-eastern Poland contained fewer micronutrients than in our research, especially Mn [17]. In another study in Poland, six varieties of winter rye fertilized with nitrogen at doses from 80 to $100 \mathrm{~kg} \mathrm{~N} \mathrm{ha}^{-1}$ were analyzed [18]. It was found in the grain of these varieties that there were, in turn, more $\mathrm{Fe}, \mathrm{Mn}$ and $\mathrm{Cu}$ [18]. In studies with 21 winter rye varieties carried out in Russia, it was found that the content of microelements in the grain varied among rye genotypes: Fe-2.1-fold, $\mathrm{Zn}-1.6$-fold and $\mathrm{Mn}-2.7$-fold [13].

In the studies of Kadłubiec and Bojarczuk [19], spring rye was cultivated on a good rye complex of soil and fertilized with nitrogen at a dose of $80 \mathrm{~kg} \mathrm{~N} \mathrm{ha}^{-1}$; in this condition, it gave a grain yield in the amount of $5.1 \mathrm{t} \mathrm{ha}^{-1}$. In the study conducted by Stępien et al. [17] with winter rye fertilized with $90 \mathrm{~kg}$ $\mathrm{N} \mathrm{ha}^{-1}$, it was found that the grain yield was about $17.5 \%$ higher than at control plots and the contents of $\mathrm{Mn}, \mathrm{Zn}$ and $\mathrm{Cu}$ were a little higher than the control. In the study of Teklić et al. [20], it was found that fertilization with higher doses of nitrogen influenced the content of $\mathrm{Fe}, \mathrm{Zn}$ and $\mathrm{Cu}$ in grain, but had no effect on the level of Mn accumulation. A similar phenomenon was observed in our own research, where a dose of 30 and $60 \mathrm{~kg} \mathrm{~N} \mathrm{ha}^{-1}$ significantly affected the Mn content (Table 6, Figure S2A and Tables S1 and S2 in the Supplementary Material for the comprehensive datasets analysis). Based on the research of Kutman et al. [21], we found that the fertilization with a high dose of $\mathrm{N}$ has a positive influence on the uptake of iron and zinc by grains of wheat. As can be seen in the literature, the used forms of $\mathrm{N}$ application have different influences on the accumulation of $\mathrm{Mn}$ in the plant. Therefore, to obtain the best results, nitrogen fertilizers should be used according to the following order: $\left(\mathrm{NH}_{4}\right)_{2} \mathrm{SO}_{4}$ $>\mathrm{NH}_{4} \mathrm{NO}_{3}>\mathrm{Ca}\left(\mathrm{NO}_{3}\right)_{2}$ [22]. 


\subsection{Sulfur}

As shown in the presented experiment, the supplementation of sulfur improved the NPK effect, because the rye grain yield increased by $80.0 \mathrm{~kg} \mathrm{ha}^{-1}(2.5 \%$ ) (see Table 6, Figure S2A, and Tables S1 and S2 in the Supplementary Material for the comprehensive dataset analysis). As is well known, nitrogen is the most yielding element. Sulfur, in turn, improves nitrogen utilization in the plant and improves the quality characteristics of plants. Klikocka and Cybulska [11] found that, after using sulfur in wheat grain, the protein, methionine and cysteine content increased, and flour baking properties improved. However, the yield of wheat grain after applying $50 \mathrm{~kg} \mathrm{Sha}^{-1}$ increased by $3.6 \%$. According to Podleśna [23], the addition of $60 \mathrm{~kg} \mathrm{~S} \mathrm{ha}^{-1}$ caused an increase in winter wheat grain yield of $11 \%$.

Our own research showed that the concentration of $\mathrm{Fe}, \mathrm{Zn}$ and $\mathrm{Cu}$ in rye grain after sulfur application at a rate of $40 \mathrm{~kg} \mathrm{ha}^{-1}$ increased in comparison with the control, by about $8.8 \%, 2.8 \%$ and 3.6\%, respectively. However, the concentration of Mn was decreased by $5.0 \%$. The uptake of $\mathrm{Fe}$, $\mathrm{Zn}$ and $\mathrm{Cu}$ by grain DM following fertilization of $40 \mathrm{~kg} \mathrm{~S} \mathrm{ha}^{-1}$ increased by $11.3 \%, 2.8 \%$ and $6.0 \%$, respectively, in comparison with the control. The addition of $S$ to NPK fertilization decreased the uptake of manganese (Mn) by rye grain DM by about $2.8 \%$ (see Table 6, Figure S2A, Table S1 in the Supplementary Material for the comprehensive dataset analysis).

Many scientific papers show that nitrogen is the most important yield-forming element. However, nitrogen fertilization is effective when the soil is rich in other nutrients, such as sulfur [11]. Barczak et al. [24] report that in conditions of sulfur deficit in soil, the yield-generating nitrogen efficiency is reduced, while more intensive nitrogen fertilization deepens sulfur shortage. This in turn inhibits the uptake of nitrogen by plants, limiting their growth and development. In the conditions of sulfur deficiency in soil, $\mathrm{N}$ fertilizer does not show optimal efficiency and causes the reduction of yields, as well as changes in the chemical composition of plants and in quality features. Because sulfur decreases soil $\mathrm{pH}$, it indirectly influences the availability of $\mathrm{Zn}, \mathrm{Fe}, \mathrm{Mn}, \mathrm{Cu}$ and other micronutrients [25-27].

\subsection{Interactions and Correlation between Nutrients}

The presented results showed that $\mathrm{S}$ supplementation with all tested $\mathrm{N}$ doses did not have a statistically significant effect on the content and uptake of the analyzed elements (see Table 6, Figure S2B and Table S1 in the Supplementary Material for the comprehensive dataset analysis).

The research results showed that the addition of sulfur to each $\mathrm{N}$ dose caused a trend of increasing the content and uptake of microelements and the yield of spring rye. This type of interaction between nitrogen and sulfur is known as the additive interaction (of sulfur) [28], because the assimilation of $\mathrm{N}$ and $\mathrm{S}$ in plants is closely related [29]. Therefore, joint fertilization with these two elements significantly influences both the uptake and metabolism of nitrogen and sulfur and other elements in the plant.

Furthermore, we observed statistically significant positive correlations between the grain yield and the content and uptake of all micronutrients (Table 7). The correlation coefficients between the content of micronutrients and the grain yield decreased in the order $\mathrm{Fe}>\mathrm{Mn}>\mathrm{Cu}>\mathrm{Zn}$. However, in the case of the correlation between the uptake of micronutrients by grain DM and the grain yield, the strength of the relationship was in the order $\mathrm{Mn}>\mathrm{Zn}>\mathrm{Cu}>\mathrm{Fe}$. On the basis of an experiment with the application of increasing doses of sulfur, Klikocka and Marks [30] found a positive correlation between the sulfur dose and the accumulation of elements in the plant. 
Table 7. Correlation coefficients between grain yield and the content and uptake of micronutrients.

\begin{tabular}{cccccccccc}
\hline Test Feature $(\boldsymbol{n}=\mathbf{2 4})$ & $\mathbf{N o}$ & $\mathbf{( 2 )}$ & $\mathbf{( 3 )}$ & $\mathbf{( 4 )}$ & $\mathbf{( 5 )}$ & $\mathbf{( 6 )}$ & $\mathbf{( 7 )}$ & $\mathbf{( 8 )}$ & $\mathbf{( 9 )}$ \\
\hline Yield of grain & $(1)$ & $\mathbf{0 . 5 9 4}$ & 0.879 & 0.546 & 0.955 & 0.452 & 0.939 & 0.513 & 0.940 \\
Fe-content & $(2)$ & - & 0.783 & -0.086 & 0.429 & -0.040 & 0.458 & 0.780 & 0.739 \\
Fe-uptake & $(3)$ & - & - & 0.235 & 0.756 & 0.315 & 0.797 & 0.592 & 0.889 \\
Mn-content & $(4)$ & - & - & - & 0.769 & 0.442 & 0.591 & 0.210 & 0.487 \\
Mn-uptake & $(5)$ & - & - & - & - & 0.498 & 0.925 & 0.471 & 0.891 \\
Zn-content & $(6)$ & - & - & - & - & - & 0.726 & -0.157 & 0.277 \\
Zn-uptake & $(7)$ & - & - & - & - & - & - & 0.343 & 0.830 \\
Cu-content & $(8)$ & - & - & - & - & - & - & - & 0.771 \\
Cu-uptake & $(9)$ & - & - & - & - & - & - & - & - \\
\hline
\end{tabular}

${ }^{\dagger}$ Bold values represent significant differences $(p \geq 0.05=0.406$ and $p \geq 0.01=0.517)$.

In the presented study, a positive correlation between the content and uptake of Fe, $\mathrm{Mn}$ and $\mathrm{Zn}$ was found. Additionally, a significant correlation was found between the content of $\mathrm{Mn}$ and $\mathrm{Cu}$, while no correlation was found between the content and uptake of $\mathrm{Zn}$ and $\mathrm{Cu}$ and additionally between the $\mathrm{Zn}$ uptake and the $\mathrm{Cu}$ content (Table 7). Based on the studied literature, it can be supposed that metallic nutrients can compete with iron and, in consequence, limit iron uptake by the plant. It has been known for a long time that $\mathrm{Fe}$ and $\mathrm{Mn}$ compete in the process of iron uptake by the plant [31]. $\mathrm{Mn}^{2+}$ has similar properties to $\mathrm{Ca}^{2+}$ and $\mathrm{Mg}^{2+}$ (alkaline cations) and $\mathrm{Fe}^{2+}$ and $\mathrm{Zn}^{2+}$ (heavy metals); therefore, these cations compete with $\mathrm{Mn}$ for transport and uptake by the plant [32]. A negative correlation between $\mathrm{Fe}$ and $\mathrm{Cu}$ accumulation in durum wheat was also observed. This phenomenon may indicate the mutual antagonism of these two elements and may affect iron deficiency in the plant [33]. It is well known that a shortage of one chemical element may influence the uptake of one or more other elements [34]. In the literature, it has been shown that, under the conditions of nutrient shortage in the soil, there is a competition in uptake, especially between $\mathrm{Mn}^{2+}$ and $\mathrm{Cu}^{2+}$ or $\mathrm{Zn}^{2+}$ [35], and between $\mathrm{Fe}^{2+}$ and $\mathrm{Zn}^{2+}$ or $\mathrm{Cu}^{2+}[36]$.

\subsection{Weather Conditions}

In the present experiment, the grain yield of spring rye as well as the accumulation and uptake of microelements were modified by the weather conditions. According to many authors, high yields of cereals are usually dependent on low rainfall during winter and April, while higher rainfall is necessary in the booting (BBCH 41-49) and flowering phase (BBCH 61-69) [37,38]. On the other hand, Tarkowski [39] reports that rye, like other cereals, shows the greatest demand for water in the period from booting (BBCH 41-49) to heading (BBCH 51-59). Chmura et al. [40] found that the water requirement of spring cereals for their optimal growth is from 230 to $300 \mathrm{~mm}$. In the research of Dopka et al. [41], the highest yield of spring rye grain was obtained when the sum of atmospheric precipitation during the vegetation period was $254.3 \mathrm{~mm}$. In our own research, the highest yield of spring rye grain (on average $3.315 \mathrm{t} \mathrm{ha}^{-1}$ ) was obtained in the vegetation season of 2011, when the sum of precipitation was $414.6 \mathrm{~mm}(\mathrm{k}=1.3)$, and the months of April $(36.2 \mathrm{~mm})$, May $(31.4 \mathrm{~mm})$ and June $(52.9 \mathrm{~mm})$ were characterized by an optimal rainfall distribution [10]. However, high atmospheric precipitation in April, May and June in 2009 and 2010 adversely affected the yield of spring rye grain. It was also found that the air temperature in the vegetation seasons of the presented experiment exceeded the average temperature over several years [10]. Rymuza et al. [42] explained that air temperature is the main factor affecting the rate of plant development, while the water factor affects the yielding of cereals, especially in the critical period between the booting (BBCH 41-49) and heading stages (BBCH 51-59).

The content and uptake of $\mathrm{Mn}$ and $\mathrm{Zn}$ as well as $\mathrm{Cu}$ uptake by the grain DM of spring rye were most positive in the weather conditions that occurred in 2011 (rather wet). In the 2009 period (rather dry), the weather conditions also had an important effect on favorable $\mathrm{Cu}$ accumulation and on $\mathrm{Fe}$ content and uptake by the grain DM of spring rye. The concentration and uptake of microelements, 
except the $\mathrm{Zn}$ content, were smallest in 2010 (period rather wet) (Table 6). This may be due to the very low precipitation in the stages of grain formation and ripening. In the study of Woźniak and Stepniewska [14], the lowest content of $\mathrm{Cu}$ was also found in the grain harvested in the year with the lowest rainfall and high air temperature. However, the content of $\mathrm{Fe}, \mathrm{Mn}$ and $\mathrm{Zn}$ in the wheat grain in the above-mentioned study was not significantly affected by weather conditions, in contrast to our own results.

\section{Conclusions}

Based on the presented research and cited literature, we can recommend the use of $\mathrm{N}-\mathrm{S}$ fertilization for spring rye in the analyzed arable soils (Cambisols-sand $68 \%$, silt $31 \%$, clay $1 \%$ and pH from 5.6 to 5.8) in the described region of Poland. Field studies have shown that the application of $S$ in an amount of $40 \mathrm{~kg} \mathrm{ha}^{-1}$ for every $\mathrm{N}$ dose is beneficial for spring rye. It should be noted, however, that the highest grain yield was obtained after the application of $90 \mathrm{~kg} \mathrm{~N} \mathrm{ha}{ }^{-1}$ and $40 \mathrm{~kg} \mathrm{~S} \mathrm{ha}^{-1}$. This means that sulfur supplementation of NPK fertilization can be recommended as a method for the agricultural biofortification of spring rye with $\mathrm{Fe}, \mathrm{Mn}, \mathrm{Zn}$ and $\mathrm{Cu}$. In the presented experiment, it was also shown that the tested features were significantly influenced by weather conditions, in particular growing seasons.

Supplementary Materials: The following are available online at http://www.mdpi.com/2073-4395/10/1/35/s1, Figure S1: The scheme of the field experiment $(52 \mathrm{~m} \times 28 \mathrm{~m})$ and plots, Figure S2: The influence of nitrogen (N) and sulfur (S) fertilization on the grain yield $\left(\mathrm{t} \mathrm{ha}^{-1}\right)$ and content $\left(\mathrm{mg} \mathrm{kg}^{-1}\right)$ of microelements in spring rye grain, Table S1: Basic data retarding the preparation of the Table 6, Table S2a: Results of statistical calculations for the studied features of spring rye, for the preparation of Table 6 and Table S1, Table S2b: Results of statistical calculations for the studied features of spring rye, for the preparation of Table 6 and Table S1, Table S3: Selyaninov's hydrothermal coefficient in the years 2009-2011 and the long-term average. Basic data for the preparation of the Table 2. Table S4: Total rainfall (mm) in 2009-2011 and long-term average. Research Station in Zamość. Basic data for the preparation of Table 2, Table S5: Air temperature $\left({ }^{\circ} \mathrm{C}\right)$ in 2009-2011 and long-term average. Research Station in Zamość. Basic data for the preparation of Table 2.

Author Contributions: Conceptualization, H.K., A.P., J.P., B.N., S.H., E.S. and E.B.; Data curation, H.K. and A.P.; Formal analysis, H.K. and A.P.; Funding acquisition, H.K., A.P. and J.P.; Investigation, H.K., A.P., J.P., B.N., S.H., E.S. and E.B.; Methodology, H.K., A.P. and B.N.; Project administration, H.K., A.P., J.P., B.N., S.H., E.S. and E.B.; Resources, H.K., A.P. and B.N.; Software, H.K., A.P. and B.N.; Supervision, J.P., S.H., E.S. and E.B., Validation, H.K., A.P. and B.N.; Visualization, H.K., A.P. and B.N.; Writing-original draft, H.K., A.P., J.P., B.N., S.H., E.S. and E.B., Writing - review \& editing, H.K., A.P. and B.N. All authors have read and agreed to the published version of the manuscript.

Funding: The research and publication of the paper was supported by the University of Life Sciences in Lublin, Poland, and by the Institute of Soil Science and Plant Cultivation, State Research Institute in Puławy, Poland.

Conflicts of Interest: The authors declare no conflict of interest.

\section{References}

1. Graham, R.D.; Welch, R.M.; Bouis, H.E. Addressing micronutrient malnutrition through enhancing the nutritional quality of staple foods: Principles, perspectives and knowledge gaps. In Advances in Agronomy; Sparks, D., Ed.; Academic Press: Cambridge, MA, USA, 2001; pp. 77-142.

2. Klikocka, H.; Głowacka, A. Does the sulphur fertilization modify magnesium and calcium content in potato tubers (Solanum tuberosum L.)? Acta Sci. Pol.-Hortoru. 2013, 12, 41-53.

3. Klikocka, H.; Cybulska, M.; Nowak, A. Efficiency of Fertilization and Utilization of Nitrogen and Sulphur by Spring Wheat. Pol. J. Environ. Stud. 2017, 26, 2029-2036. [CrossRef]

4. Klikocka, H.; Haneklaus, S.; Bloem, E.; Schnug, E. Influence of sulphur fertilization on infestations of potato tubers (Solanum tuberosum L.) with Rhizoctonia solani and Streptomyces scabies. J. Plant Nutr. 2005, 28, 819-833. [CrossRef]

5. Klikocka, H. The sulphur status in biosphere and plant fertilization. Przem. Chem. 2010, 89, 903-908.

6. Klikocka, H. The effect of sulphur kind and dose on content and uptake micro-nutrients by potato tubers (Solanum tubersosum L.). Acta Sci. Pol.-Hortoru. 2011, 10, 137-151. 
7. Tabak, M.; Lepiarczyk, A.; Filipek-Mazur, B.; Bachara, P. The effect of fertilization with ammonium nitrate enriched with ammonium sulfate on the quantity and quality of winter wheat grain yield as well as on soil properties. Plant Soil Environ. 2019, 65, 211-217. [CrossRef]

8. Siebielec, G.; Smreczak, B.; Klimkowicz-Pawlas, A.; Kowalik, M.; Kaczyński, R.; Koza, P.; Ukalska-Jaruga, A.; Łysiak, M.; Wójtowicz, U.; Poręba, L.; et al. Report from the third stage of the contract implementation. In Monitoring of Chemistry of Arable Soils in Poland in 2015-2017; IUNG-PIB Puławy: Puławy, Poland, 2017; pp. 1-170.

9. Klikocka, H. Resources of sulphur in Poland and its importance in industry and agriculture. Przem. Chem. 2011, 90, 1728-1737.

10. Narolski, B. Evaluation of the yield-increasing role of sulphur and nitrogen in spring rye in production. In Doctors Dissertation; IUNG-PIB Puławy: Puławy, Poland, 2016; pp. 1-141.

11. Klikocka, H.; Cybulska, H. Sulphur and nitrogen fertilization of spring wheat. In Mineral Fertilization of Spring Wheat; Saarbrucken LAP Lambert Academic Publishing: Saarbrücken, Germany, 2014; pp. 1-122.

12. IUSS Working Group WRB. World Reference Base for Soil Resources 2014, Update 2015; International Soil Classification System for Naming Soils and Creating Legends for Soil Maps. World Soil Resources Reports No. 106; FAO: Rome, Italy, 2015.

13. Bityutskii, N.; Yakkonen, K.; Loskutov, I. Content of iron, zinc and manganese in grains of Triticum aestivum, Secale cereale, Hordeum vulgare and Avena sativa cultivars registered in Russia. In Genetic Resources and Crop Evolution (Genet. Resour. Crop Evol.); Springer Science+Business Media Dordrecht: Berlin, Germany, 2017; pp. 1-7. [CrossRef]

14. Woźniak, A.; Stępniowska, A. Yield and quality of durum wheat grain in different tillage systems. J. Elem. 2017, 22, 817-829. [CrossRef]

15. Ragaee, S.; Abdel-Aal, E.M.; Noaman, M. Antioxidant activity and nutrient composition of selected cereals for food use. Food Chem. 2006, 98, 32-38. [CrossRef]

16. Kan, A. Characterization of the fatty acid and mineral composition of selected cereal cultivars from Turkey. Rec. Nat. Prod. 2015, 9, 124-134.

17. Stępień, A.; Wojtkowiak, K.; Pietrusewicz, M.; Skłodowski, M.; Pietrzak-Fiećko, R. The yield and grain quality of winter rye (Secale cereale L.) under the conditions of foliar fertilization with micronutrients $(\mathrm{Cu}, \mathrm{Zn}$ and Mn). Pol. J. Nat. Sci. 2016, 31, 33-46.

18. Kowieska, A.; Lubowicki, R.; Jaskowska, I. Chemical composition and nutritional characteristics of several cereal grain. Acta Sci. Pol. Zootech. 2011, 10, 37-50.

19. Kadłubiec, W.; Bojarczuk, J. Assessment of interaction of spring triticale and spring rye families with the environment. Commun. Biul. IHAR. 2003, 230, 187-193. (In Polish)

20. Teklić, T.; Lončarić, Z.; Kovačević, V.; Singh, B.R. Metallic trace elements in cereal grain-A review: How much metal do we eat? Food Energy Secr. 2013, 2, 81-95. [CrossRef]

21. Kutman, U.B.; Yildiz, B.; Cakmak, I. Improved nitrogen status enhances Zn and Fe concentrations both in the whole grain and the endosperm fraction of wheat. J. Cereal Sci. 2011, 53, 118-125. [CrossRef]

22. Wojtkowiak, K.; Stępień, A.; Pietrzak-Fiećko, R.; Warechowska, M. Effects of nitrogen fertilization on the yield, micronutrient content and fatty acid profiles of winter wheat (Triticum aestivum L.) varieties. J. Element. 2018, 23, 483-494.

23. Podleśna, A. Studies on role of sulfur at forming of mineral management and height and quality of chosen crops yield. Habilitation thesis. In Monografie i Rozprawy Naukowe; IUNG-PIB Puławy: Puławy, Poland, 2013; p. 37.

24. Barczak, B.; Klikocka, H.; Kozera, W. Assessment of the effect of sulphur fertilization on the yield and micronutrient accumulation of oat grain. J. Element. 2018, 23, 45-56.

25. Williams, D.E.; Vlamis, J. Comparative accumulation of manganese and boron in barley tissues. Plant Soil. 1971, 33, 623-628.

26. Shuman, L.M. Micronutrient fertilizers. J. Crop Prod. 1998, 1, 165-195. [CrossRef]

27. Haneklaus, S.; Bloem, E.; Schnug, E. Sulphur interactions in crop ecosystems. In Sulfur in Plants: An Ecological Perspective (Plant Ecophysiology); Hawkesford, M.J., De Kok, L.J., Eds.; Springer: Dordrecht, The Netherlands, 2007; pp. 17-58.

28. Grzebisz, W. Fertilization of crops. Part, I. Basics of fertilizing; PWRiL: Poznań, Poland, 2008; p. 428. (In Polish)

29. Fageria, V.D. Nutrient interactions in crop plants. J. Plant Nutr. 2001, 24, 1269-1290. [CrossRef] 
30. Klikocka, H.; Marks, M. Sulphur and nitrogen fertilization as a potential means of agronomic biofortification to improve the content and uptake of microelements in spring wheat grain DM. J. Chem. 2018, 2018, 1-20. [CrossRef]

31. Johnson, M.O. Manganese as a cause of the depression of the assimilation by iron by pineapple plants. Ind. Eng. Chem. 1917, 9, 47-49. [CrossRef]

32. Maschner, H. Mineral Nutrition of Higher Plants, 2nd ed.; Academic Press: Boston, MA, USA, 1995.

33. Michaud, A.M.; Chappellaz, C.; Hinsiger, P. Copper phytotoxicity affects root elongation and iron nutrition in durum wheat (Triticum turgidum durum L.). Plant Soil. 2008, 310, 151-165. [CrossRef]

34. Kochian, L.V. Mechanism of micronutrient uptake and translocation in plants. In Micronutrients in Agriculture; Mortvedt, J.J., Cox, F.R., Shuman, L.M., Welch, R.M., Eds.; Soil Science Society of America: Madison, WI, USA, 1991; pp. 229-296.

35. del Rio, L.A.; Sevilla, F.; Gómez, M.; Yànez, J.; López-Gorgé, J. Superoxide dismutase: An enzyme system for the study of micronutrient interactions in plants. Planta 1978, 140, 221-225. [CrossRef]

36. Rengel, Z.; Graham, R.B. Wheat genotypes differ in Zn efficiency when grown in chelate-buffered nutrient solution. II. Nutrient uptake. Plant Soil 1995, 176, 317-324. [CrossRef]

37. Gassiorowska, B.; Koc, G.; Buraczyńska, D.; Struk, K. Impact of weather conditions on the yield of cereals cultivated at the Agricultural Experimental Station in Zawady. Infrastrukt. I Ekol. Teren. Wiej./Infrastruct. Ecol. Rural Areas. 2011, 6, 91-99.

38. Gooding, M.; Ellis, R.H.; Shewry, P.R.; Schofield, J.D. Effects of restricted water availability and increased temperature on the grain filling, drying and quality of winter wheat. J. Cereal Sci. 2003, 37, 295-309. [CrossRef]

39. Tarkowski, C. Rye Biology; Wyd: PWN Warszawa, Poland, 1983; pp. 1-367.

40. Chmura, K.; Chylińska, E.; Dmowski, Z.; Nowak, L. The role of the water factor in shaping the yield of selected field plants. Infrastrukt. I Ekol. Teren. Wiej./Infrastruct. Ecol. Rural Areas. 2009, 9, 33-44.

41. Dopka, D.; Korsak-Adamowicz, M.; Starczewski, J. Impact of selected physical soil properties on spring rye yielding. Fragm. Agron. 2007, 1, 33-40.

42. Rymuza, K.; Marciniuk-Kluska, A.; Bombik, A. Yielding of winter cereals depending on thermal and precipitation conditions in the production fields of the Agricultural Experimental Station in Zawady. Woda-Śr.-Obsz. Wiej. 2012, 12, 207-220. 